\title{
Global Environmental Warfare
}

\author{
J. Marvin Herndon, Ph.D \\ Transdyne Corporation, San Diego, California, USA \\ Mark Whiteside, M.D., M.P.H. \\ Florida Department of Health in Monroe County, Key West, Florida, USA
}

\begin{abstract}
Unlike traditional forms of warfare that cause environmental harm as collateral damage, today vast segments of biota-populations, including humans, are at risk from undeclared global environmental warfare, undertaken through deception and deceit, orchestrated by undisclosed perpetrators for undisclosed purposes. As we reveal here, the purported goal of preventing environmental warfare was the key to developing a means to co-opt sovereign nations into waging covert, highly destructive environmental warfare against their own citizens. The means involved deceiving leaders of sovereign nations into signing onto a deceptively-worded "Trojan horse" international treaty ostensibly to prohibit environmental warfare, but which specifically does not prohibit "peaceful" environmental modification where "environmental modification techniques" refers to any technique for changing - through the deliberate manipulation of natural processes the dynamics, composition or structure of the Earth, including its biota, lithosphere, hydrosphere and atmosphere, or of outer space." Moreover, that international treaty mandates contribution and co-operation in unspecified environmental modification, by unspecified entities, without specificity of risks to human and environmental health. Although "environmental modification techniques" are applied and conducted with secrecy and deception, the horrific environmental damage, ascertained by scientific forensic investigations and reviewed here, cannot possibly be considered "peaceful" but instead constitute global environmental warfare. Citizens everywhere must wake up, look up, speak up, and demand an end to this environmental warfare.
\end{abstract}

Keywords: Environmental warfare; ENMOD; Geoengineering; Particulate pollution; Environmental modification.

\section{INTRODUCTION}

Historically, modern warfare, waged by and between readily identifiable nation-states or assemblages of nation-states, results in environmental harm as collateral damage. Today, however, large segments of humanity and other biota are at risk from global environmental warfare, undertaken through deception and deceit by undisclosed globalist-type factions who remain in the shadows.

Concerning the United States, in 1838 Abraham Lincoln famously stated [1]: "At what point, then, is the approach of danger to be expected? I answer if it ever reach us it must spring up amongst us. It 
cannot come from abroad. If destruction be our lot, we must ourselves be its author and finisher." To some, Lincoln's remark might seem to connote the likelihood of coup d'état, which, of course, is an ever-present danger. Another possibility, yet unrecognized by national security officials and strategic analysts, but disclosed here, is that an entity from abroad might discover the means to coopt sovereign nations' military and government functions into waging covert, highly destructive environmental warfare against their own citizenry.

In 1968 notable geophysicist Gordon J. F. MacDonald [2] authored a book-chapter entitled "How to Wreck the Environment" in which he wrote: "Among future means of obtaining national objectives by force, one possibility hinges on man's ability to control and manipulate the environment of his planet." MacDonald described how the forces of nature might be surreptitiously turned against enemy nations with devastating consequences. MacDonald foresaw the future potentialities of environmental warfare, but his use of the phrase "national objectives" indicates a traditional nationstate concept of warfare. During the next fifty years much of what MacDonald described became not only possible but a reality with new technology that he had not envisioned [3].

Environmental warfare was documented during the Viet Nam War with the wide-spread use of the chemical defoliant, Agent Orange [4], and with cloud seeding operations to cause additional rainfall over the Ho Chi Minh Trail to impede movement of troops and supplies [5]. Nevertheless, unlike nuclear warfare, which previously had been released from Pandora's Box [6], environmental warfare was yet in its infancy. Preventing environmental warfare was an idea people everywhere might willingly embrace. But as revealed here, the hope of preventing environmental warfare was the key for realizing a means to co-opt sovereign nations into waging covert, highly destructive environmental warfare against their own citizens. The means involved deceiving leaders of sovereign nations into signing onto a deceptively-worded "Trojan horse" international treaty, sometimes referred to as ENMOD [7].

\section{TROJAN HORSE}

The United Nations international treaty, "Convention on the Prohibition of Military or Any Other Hostile Use of Environmental Modification Techniques," through concerted efforts by the United States and the Soviet Union [8] was entered into force on October 5, 1978 [7].

The following are highlights of a legal critique of ENMOD [7] published previously [9].

Logically, the term "environmental modification techniques", that which is being prohibited, should be defined prior to its prohibition. But that is not the case here. The term "environmental modification techniques", is defined quite precisely and in the broadest possible terms in Article II, which states: "As used in article 1, the term "environmental modification techniques" refers to any technique for changing - through the deliberate manipulation of natural processes - the dynamics, composition or structure of the Earth, including its biota, lithosphere, hydrosphere and atmosphere, or of outer space."

The "prohibitive terminology" Article I is not prohibitive at all as it uses the non-binding phrase "undertakes not to" instead of the prohibitive "shall not" which would carry the force of law. 
Article III that actually mandates compliance on activities not connected in any way with the subject expressed by the ENMOD [7] title. It is a Trojan horse: Article III deceptively mandates environmental modification not at all indicated by its title.

- Article III, Section 1, by the use of shall, mandates that there shall be no prohibition whatsoever on the use of environmental modification techniques "for peaceful purposes."

- Article III Section 2, although confusingly written, is clearly understandable when some of the unessential words are removed: "States Parties ... shall contribute, alone or together with other States or international organizations, to...co-operation in the preservation, improvement and peaceful utilization of the environment."

ENMOD does not prohibit environmental warfare, but instead mandates environmental modification within the range and domain described by Article II that is not connected by intent with its title. Moreover, ENMOD fails to define "international organizations" or "peaceful" or "improvement of the environment." Furthermore, ENMOD does not specify the purpose, nature, time, cost, level of commitment, and the risks to human health and to environmental harm to which all humanity may be subject (Figure 1) via mandated "contributions" from "States Parties."

As we demonstrate below, any modification of Earth's natural environment, vis-à-vis Article II, cannot be peaceful, as it disrupts the delicate balance by and between myriad biota and their environments $[10,11]$.

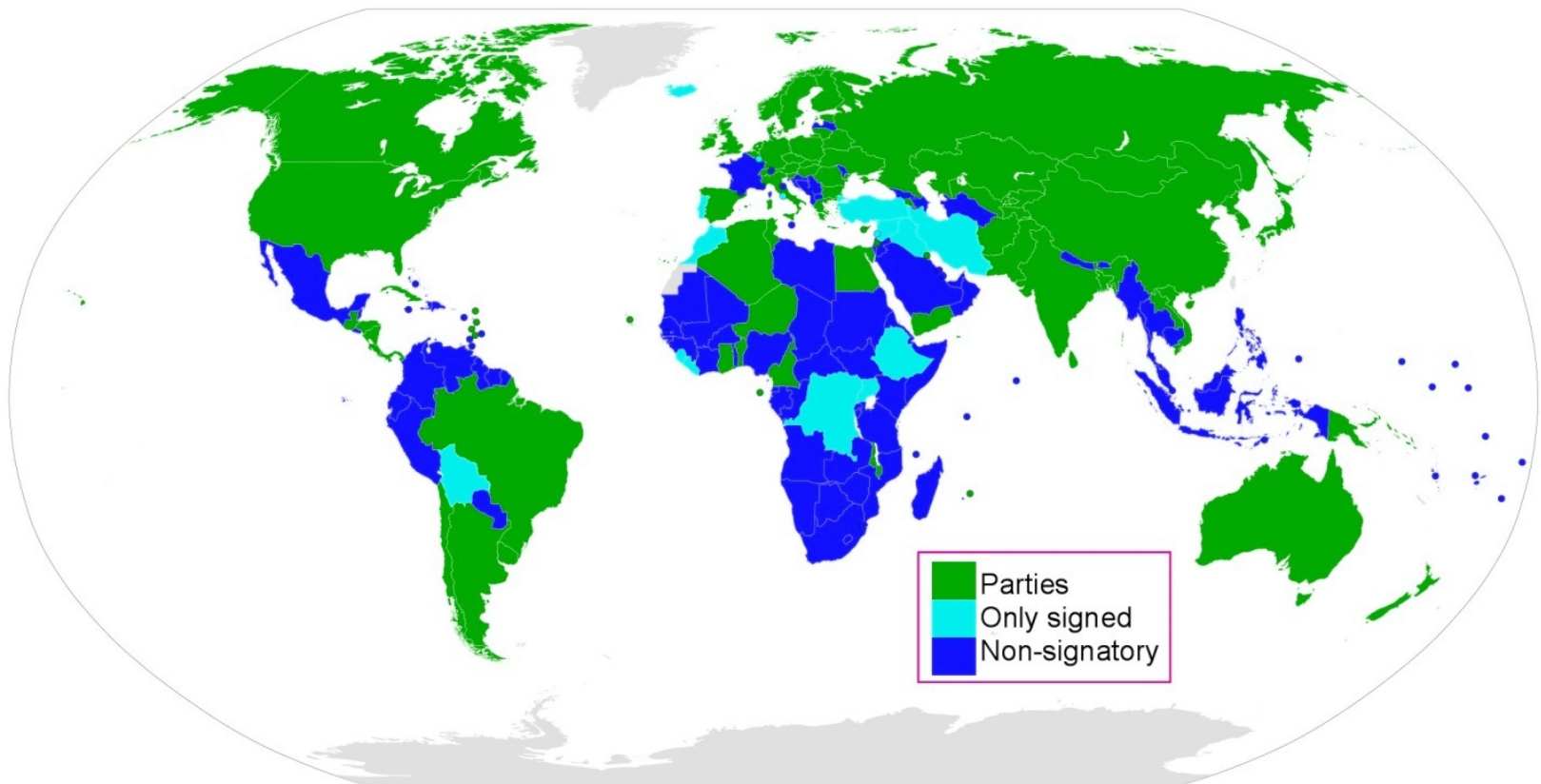

Figure 1. A public domain image showing the January 3, 2018 distribution of ENMOD signers. Adapted from [9].

\section{TEST OF TRUTH}

Law and science are pillars of civilization. Each in its own way has helped to lead humanity from an untamed and chaotic wilderness toward a better understanding of the ways to live harmoniously with one another and within the sustainable limits of the complex, interrelationships between multiple biota and the various environments of Earth. Despite differing philosophical approaches 
[12], the progress of both law and science are inextricably connected to the necessity of truth and transparency. Yet both truth and transparency in law and science are opposed by the dark side of human nature. Truth invariably becomes compromised with the absence of honesty and transparency $[13,14]$.

Truth is inextricably connected to the progress of an enlightened society whereas absence of truth is invariably associated with inhumane, totalitarian regimes.

On January 30, 1933, after Adolf Hitler had been Chancellor for only a few hours, Herman Goering addressed the German people by radio and announced: "A new chapter opens today and in this chapter liberty and honor will constitute the very basis of the new State." Soon thereafter, Hitler seized the labor unions, their bank accounts, and pension assets [15] and, subsequently, committed crimes against humanity [16].

Particulate trails across the sky, like those shown in Figure 2, have concerned observant citizens for at least two decades, especially as they have become more frequent occurrences $[17,18]$. Not only has there been no public disclosure as to the nature of the particulates jet-sprayed into the region where clouds form, but there has been a systematic pattern of false information alleging the trails to be harmless ice-crystal contrails from moisture from engine exhaust [19-21].

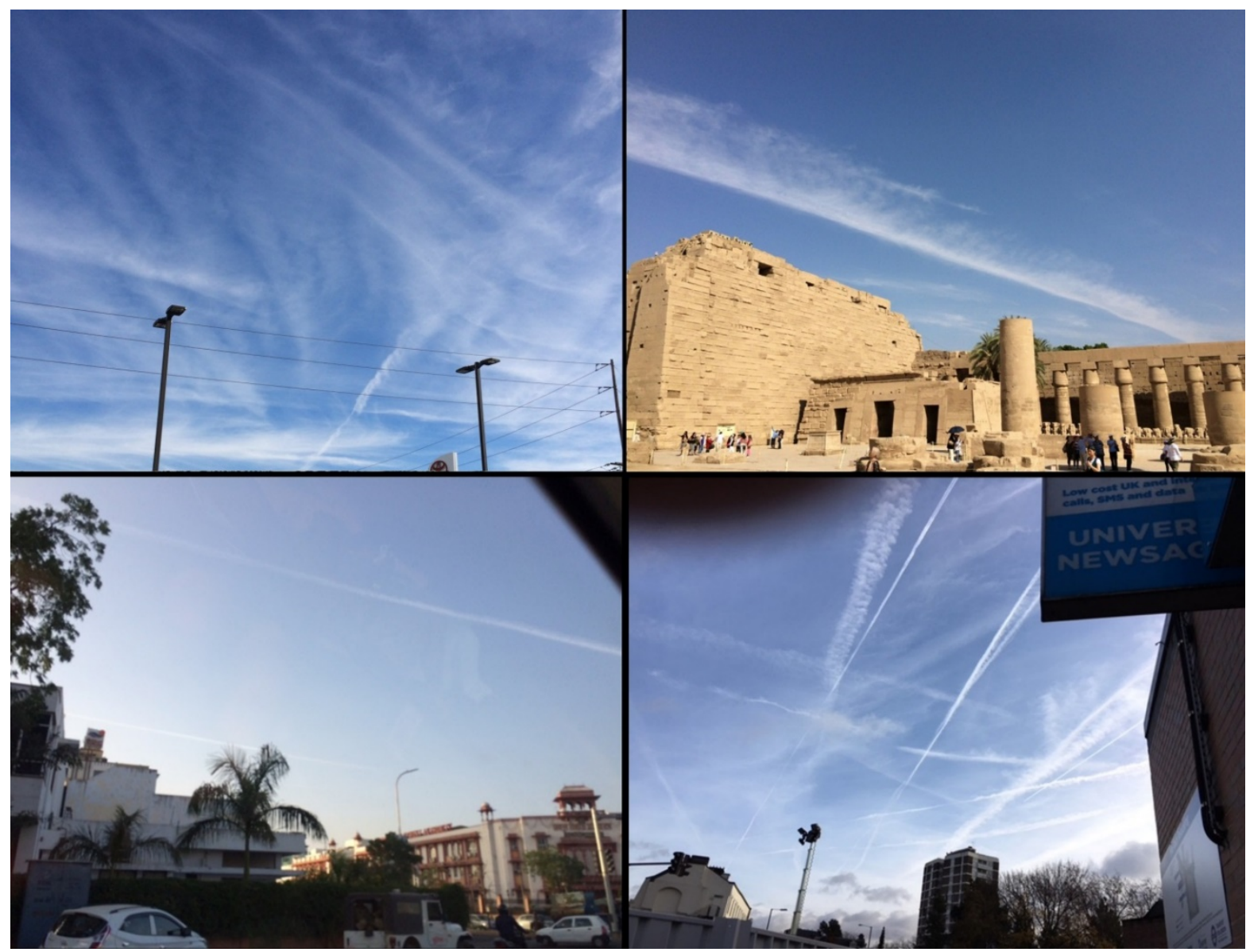

Figure 2. Environmental modification tropospheric particulate trails. Clockwise from upper left: San Diego, California, USA; Karnack, Egypt; London, England; Jaipur, India. From [9]. 
Contrails only superficially resemble the particulate trails. Contrails form under very humid, very cold atmospheric conditions, appearing as short trails that evaporate quickly to become invisible gas [22]. Particulate trails, on the other hand, spread out and for a brief time resemble cirrus clouds before becoming a white haze in the sky. The contrail disinformation stands in conflict with observations [23] and is disputed by scientific evidence [24].

\section{ENVIRONMENTAL WARFARE}

When does peaceful environmental improvement, as defined by ENMOD [7] Article II, become a new form of warfare, facilitated by the deceptively worded ENMOD Trojan horse? By definition, warfare is an activity undertaken by a political unit to destroy another [25]. In the following we describe activities, sanctioned by ENMOD, that, we posit, constitute undeclared acts of environmental warfare. Warfare may also be defined as violent, organized, and purposeful. Environmental warfare conducted under aegis of ENMOD [7] fulfills those criteria.

There is no truthful public disclosure concerning the aerial particulate emplacement. Nevertheless, it is possible to deduce the intentions of this global operation from the physical behavior of aerosol particles in the lower portion of the atmosphere, called the troposphere (Figure 3).

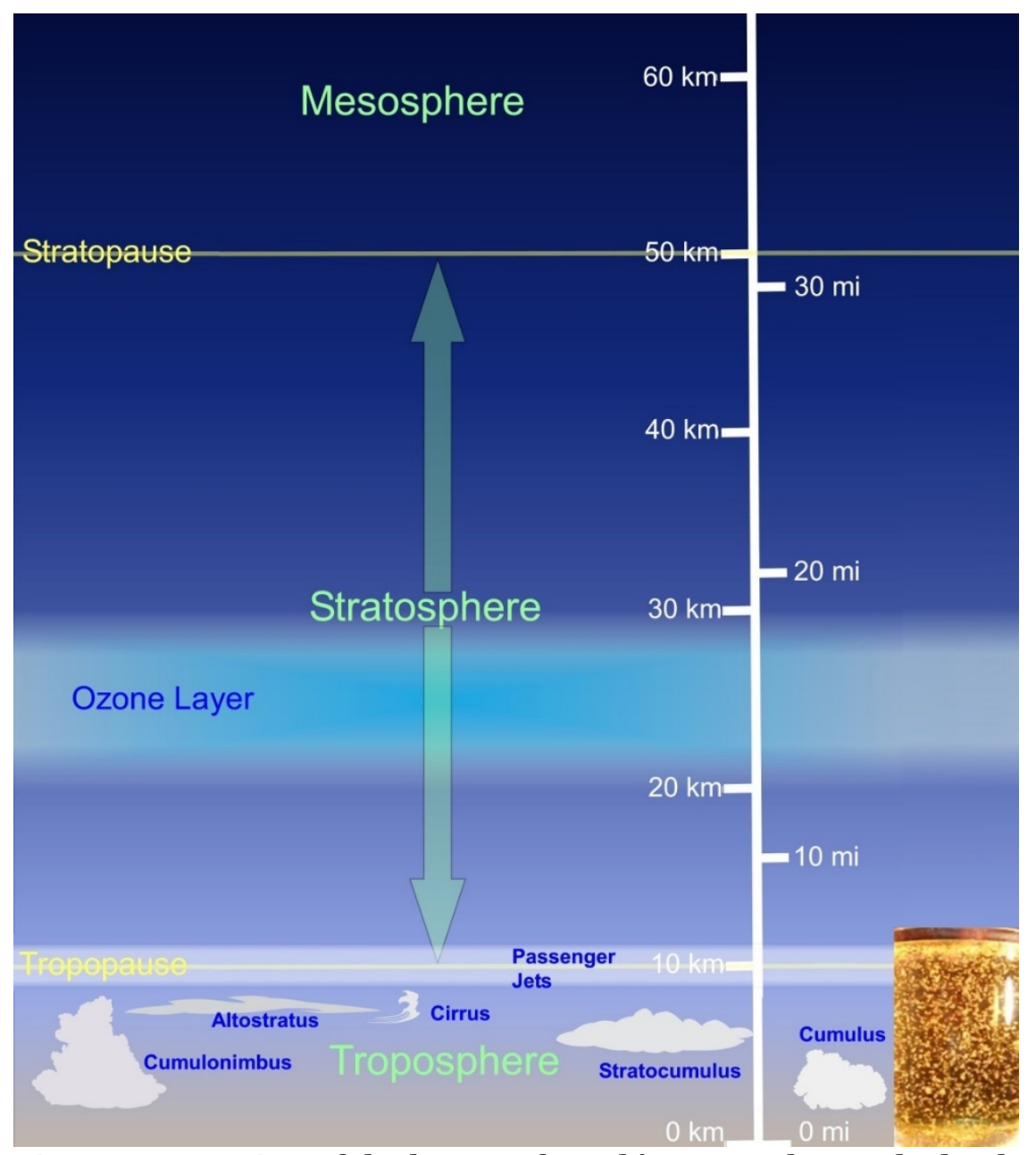

Figure 3. Schematic representation of the layers of Earth's atmosphere. The beaker-symbol in the lower right indicates the vertical region in which atmospheric convection takes place. From [26]. 
The atmosphere consists principally of two main parts, troposphere and stratosphere. There is little vertical movement of air in the stratosphere, but that is not the case for the troposphere. Air at the bottom of the troposphere is heated by the surface. The warm air rises, displacing the cooler air in the higher altitudes of the troposphere. This vertical atmospheric circulation, called convection, is an important mechanism for surface heat removal. The greater the temperature difference between the top and bottom of the troposphere, the more efficient is surface-heat removal by atmospheric convection $[26,27]$.

Whereas particles emplaced into the stratosphere tend to remain suspended for months, particles emplaced into the troposphere fall to the surface in a matter of days as a consequence of the convection-driven air circulation [28-31].

Particles in the upper regions of the troposphere are heated by short- and long-wave radiation from the Sun and by long-wave radiation from Earth's surface. That heat is transferred to the atmosphere by collisions with air molecules, thus raising the temperature of the upper tropospheric air [32]. This lowers the temperature difference relative to near-surface air, thus reducing convective heatloss efficiency [26].

The primary consequence of jet-emplaced particles is to retard heat-loss from the surface thus causing surface warming locally and/or globally [26, 27, 32-36]. Thus, one can legitimately infer that one purpose of the near-daily, near-global particulate emplacement is to cause global warming. Pollution particles, upon settling to Earth's surface, continue to absorb solar radiation, heating the surface. Upon settling on snow and ice, they can cause melting and also reduce sunlight-reflection (albedo), contributing to additional global warming [36].

Just as it is possible to deduce the intentions of the global environmental modification operations from the physical behavior of aerosol particles in the lower atmosphere, it is also possible to deduce critical information, not divulged to the public, about the nature of the substances being emplaced into the troposphere, their consequences on the planetary environment [32, 37], their risks to public health [38-41], and their potential harm to agriculture and the environment [9, 23, 42-48].

\section{TOXIC AEROSOL PARTICULATES}

The relative proportion of chemical elements measured in samples of rainwater collected after aerosol particulate emplacement are consistent with the relative proportion of elements waterextracted in the laboratory from coal fly ash, the waste-product of industrial coal-burning [49-51]. Similarly, the relative proportion of chemical elements measured in particle-trapping snow following the jet-spray activities are consistent with the relative proportion of elements measured in coal fly ash $[23,42,48,52]$.

Coal fly ash forms in the hot vapors above the burner in coal-fired utilities [51, 53, 54]. In Western nations coal fly ash is trapped by filters, mainly electrostatic [55], and sequestered in lined ponds, rather than being allowed to exit from smokestacks. The nano- and fine particle sizes that occur in coal fly ash are an ideal size for aerial spraying into the troposphere [56], ideal, except that the constituents of coal fly ash are extremely toxic, containing radioactive elements and heavy metals [51, 57-59]. 
Aerosol particulates other than coal fly ash are occasionally used for tropospheric emplacement. Black carbon, for example, has a greater capacity to heat the atmosphere, but it is more expensive and leaves highly-visible black trails across the sky $[32,60,61]$. Black carbon also poses health risks $[62,63]$.

Generally, the consequence of the near-daily, near-global tropospheric aerosol-particle emplacement is to cause global warming in excess of warming that results from other forms of heattrapping, such as greenhouse gases and particulate pollution [26, 27, 33-36], as well as from increases in heat produced within the Earth [64]. Additionally, tropospheric aerosol geoengineering particulates inhibit rainfall, causing droughts by preventing water droplets from coalescing to become sufficiently massive to fall as rain [65]. Eventually, the cloud-borne moisture-overload releases, causing storms, deluges, and floods [3, 23].

The global warming produced as a consequence of tropospheric particulates increases surfacewater evaporation and concomitantly increases rainfall [52], causes climate chaos, and disrupts more-or-less stable weather patterns that have made agriculture possible [23, 66-69]. Aerosol particles also block sunlight, adversely affecting crop growth [70] and solar electricity generation [71].

When aerosolized coal fly ash contacts atmospheric water droplets, as many as 38 chemical elements are partially extracted from the ash and dissolve into the water, which makes the water more electrically conducting [51]. The enhanced conductivity permits electromagnetic radiation to be used for manipulating weather-fronts [23]. The chemical elements that are extracted into atmospheric moisture, however, poison the environment, especially trees and forests [44].

Aerial particulate emplacement into the troposphere, such as shown in Figure 2, is deliberate air pollution. Jet-spraying air pollution particulates - especially, coal fly ash - into the troposphere for environmental modification has a variety of known adverse consequences for human health, perhaps some others yet unknown. Air pollution particles are the leading environmental cause of morbidity and mortality [72, 73], rates of which are increasing at an alarming rate [74]. Extensive studies [75] exist of the adverse health effects of air pollution particles $\leq 2.5 \mu$ across $\left(\mathrm{PM}_{2.5}\right)$, approximately the same particlesize range as aerosolized coal fly ash [76], and are thus a useful guide.

Atmospheric convection disperses the geoengineering aerosol pollution particulates throughout the troposphere including into the air we breathe. Inhaled, the tiny particles settle deep in terminal airways producing many toxic effects including decreased host defenses, tissue inflammation, altered cellular redox balance toward oxidation, and genotoxicity [40]. Ultrafine particles and nanoparticles are small enough to pass through lung tissue directly into the bloodstream $[77,78]$. Combustion-derived spherical magnetite pollution nano-particulates, similar to those found in coal fly ash [79], are found in the brains of persons with dementia [80, 81]. Furthermore, reactive iron magnetic particulates were recently found in abundance in the hearts of persons from highly polluted areas [82].

Air pollution is a major contributor to stroke, heart, and neurodegenerative disease [39, 80, 82, 83], lung cancer [38], COPD [40], respiratory infections [84], and asthma [74]. Particulate air pollution is a risk factor for cognitive decline [85-88], decreased male fertility [89], increased premenopausal 
breast cancer [90], and for Alzheimer's Dementia later in life [85]. Particulate air pollution is also a risk factor for Autism Spectrum Disorder in children [91, 92], and for children having cognitive defects $[87,88]$. Recently, scientists and physicians have shown the likely association of aerosol $\mathrm{PM}_{2.5}$ pollution with serious consequences of COVID-19 [93, 94].

The pervasive environmental modification aerial particulate spraying is harmful to virtually all life on Earth, specifically, contributing to global warming [36], disrupting habitats [52], contaminating the environment with mercury [42], decimating populations of insects [45], bats [43], and birds [46], as well as killing forests [44], exacerbating wildfires [23], enabling harmful algae in our waters [47], and destroying the ozone layer that shields surface-life from the sun's deadly ultraviolet radiation [37].

\section{CONCLUSIONS}

The natural environment cannot suffer large-scale geoengineering alteration without adversely causing "widespread, long-lasting or severe effects" on humans and other biota. Global environmental modification as described above is extremely hostile, not "peaceful" and rightfully should be considered environmental warfare.

It is well known by the World Health Organization of the United Nations [74, 95] and others [72, 73] that aerial particulate pollution is the leading environmental cause of morbidity and mortality. The ENMOD [7] sanctioned widespread deliberate poisoning of the air humans breathe with massive quantities of toxic particulate pollutants can only be described as engaging in environmental warfare. Jet-spraying particulates into the troposphere is in fact a weapon of war [48] that can lead to drought, crop failures, human and livestock suffering, and even to starvation. These consequences are clearly at odds with the Preamble of the World Health Organization which states [96] in part: "the enjoyment of the highest attainable standard of health is one of the fundamental rights of every human being."

The near-daily, near-global jet-emplacement of pollution particulates into the troposphere has so far been conducted under the highest imaginable level of secrecy and disinformation. Consequently, the identity of those responsible for ordering environmental warfare, the specific "States Parties" or the United Nations itself, remains a mystery, as does the question of underlying motives. But the harmful consequences, as discussed above, are unambiguous from the cited scientific results, and will worsen. People everywhere need to wake up, look up, speak up, and demand an end to this environmental warfare.

\section{References}

1. Lincoln, A., Address to the Young Men's Lyceum of Springfield, Illinois. Abraham Lincoln: Speeches and Writing, 1832. 1858: p. 28-36.

2. MacDonald, G.J., How to wreck the environment. Unless Peace Comes: A Scientific Forecast of New Weapons, 1968: p. 181-205.

3. Herndon, J.M., M. Whiteside, and I. Baldwin, Fifty Years after "How to Wreck the Environment": Anthropogenic Extinction of Life on Earth. J. Geog. Environ. Earth Sci. Intn., 2018. 16(3): p. 1-15. PDF

4. Stellman, J.M., et al., The extent and patterns of usage of Agent Orange and other herbicides in Vietnam. Nature, 2003. 422(6933): p. 681-687.

5. Norman, C., Pentagon admits Vietnam rainmaking. Nature, 1974. 249(5456): p. 402-402.

6. Gallagher, C., American Ground Zero: The Secret Nuclear War, 1993, Random House: New York. 
7. ENMOD, http://www.un-documents.net/enmod.htm

8. Juda, L., Negotiating a treaty on environmental modification warfare: the convention on environmental warfare and its impact upon arms control negotiations. International Organization, 1978. 32(4): p. 975-991.

9. Herndon, J.M., M. Whiteside, and I. Baldwin, The ENMOD treaty and the sanctioned assault on agriculture and human and environmental health. Agrotechnology, 2020. 9(191): p. 1-9. PDF

10. Lovelock, J. and L. Margulis, The Gaia Hypothesis, 2007, New York.

11. Lovelock, J.E. and L. Margulis, Atmospheric homeostasis by and for the biosphere: the Gaia hypothesis. Tellus, 1974. 26(1-2): p. 2-10.

12. Herndon, J.M., Some reflections on science and discovery. Curr. Sci., 2015. 108(11): p. 1967-1968. PDF

13. Scharf, M.P., The case for a permanent international truth commission. Duke J. Comp. \& Int'I L., 1996. 7: p. 375.

14. Herndon, J.M., Corruption of Science in America, in The Dot Connector2011, France. PDF

15. Delarue, J., The Gestapo: History of Horror2008: Frontline books.

16. Friedlander, H., The Origins of Nazi Genocide: From Euthanasia to the Final Solution 1995, Chapel Hill, North Carolina, USA: University of North Carolina Press.

17. Thomas, W., Chemtrails Confirmed2004, Carson City, Nevada (USA): Bridger House Publishers.

18. http://www.nuclearplanet.com/websites.pdf

19. http://www.nuclearplanet.com/USAF.pdf

20. Shearer, C., et al., Quantifying expert consensus against the existence of a secret large-scale atmospheric spraying program. Environ. Res. Lett., 2016. 11(8): p. p. 084011.

21. Tingley, D. and G. Wagner, Solar geoengineering and the chemtrails conspiracy on social media. Palgrave Communications, 2017. 3(1): p. 12.

22. Schumann, U., On conditions for contrail formation from aircraft exhausts. Meteorologisch Zeitschrift, 1996. N.F.5: p. 423.

23. Herndon, J.M. and M. Whiteside, California wildfires: Role of undisclosed atmospheric manipulation and geoengineering. J. Geog. Environ. Earth Sci. Intn., 2018. 17(3): p. 1-18. PDF

24. Herndon, J.M., R.D. Hoisington, and M. Whiteside, Chemtrails are not contrails: Radiometric evidence. J. Geog. Environ. Earth Sci. Intn., 2020. 24(2): p. 22-29. PDF

25. https://www.merriam-webster.com

26. Herndon, J.M., Role of atmospheric convection in global warming. J. Geog. Environ. Earth Sci. Intn., 2019. 19(4): p. 1-8. PDF

27. Herndon, J.M., Air pollution, not greenhouse gases: The principal cause of global warming. J. Geog. Environ. Earth Sci. Intn., 2018. 17(2): p. 1-8. PDF

28. Poet, S., H. Moore, and E. Martell, Lead 210, bismuth 210, and polonium 210 in the atmosphere: Accurate ratio measurement and application to aerosol residence time determination. Journal of Geophysical Research, 1972. 77(33): p. 6515-6527.

29. Baskaran, M. and G.E. Shaw, Residence time of arctic haze aerosols using the concentrations and activity ratios of 210Po, 210Pb and 7Be. Journal of Aerosol Science, 2001. 32(4): p. 443-452.

30. Quinn, P., et al., Short-lived pollutants in the Arctic: their climate impact and possible mitigation strategies. Atmospheric Chemistry and Physics, 2008. 8(6): p. 1723-1735.

31. Ogren, J. and R. Charlson, Elemental carbon in the atmosphere: cycle and lifetime. Tellus B, 1983. 35(4): p. 241-254.

32. Herndon, J.M. and M. Whiteside, Geophysical consequences of tropospheric particulate heating: Further evidence that anthropogenic global warming is principally caused by particulate pollution. Journal of Geography, Environment and Earth Science International, 2019. 22(4): p. 1-23. PDF

33. Herndon, J.M., Scientific misrepresentation and the climate-science cartel. J. Geog. Environ. Earth Sci. Intn., 2018. 18(2): p. 1-13. PDF 
Herndon, J. M., \& Whiteside, M. (2020) Global Envionment Warfare. Advances in Social Sciences Research Journal, 7(4) 411-422.

34. Herndon, J.M., Fundamental climate science error: Concomitant harm to humanity and the environment J. Geog. Environ. Earth Sci. Intn., 2018. 18(3): p. 1-12. PDF

35. Herndon, J.M., World War II holds the key to understanding global warming and the challenge facing science and society. J. Geog. Environ. Earth Sci. Intn., 2019. 23(4): p. 1-13. PDF

36. Herndon, J.M. and M. Whiteside, Further evidence that particulate pollution is the principal cause of global warming: Humanitarian considerations. Journal of Geography, Environment and Earth Science International, 2019. 21(1): p. 1-11. PDF

37. Herndon, J.M., R.D. Hoisington, and M. Whiteside, Deadly ultraviolet UV-C and UV-B penetration to Earth's surface: Human and environmental health implications. J. Geog. Environ. Earth Sci. Intn., 2018. 14(2): p. 1-11. PDF

38. Whiteside, M. and J.M. Herndon, Coal fly ash aerosol: Risk factor for lung cancer. Journal of Advances in Medicine and Medical Research, 2018. 25(4): p. 1-10. PDF

39. Whiteside, M. and J.M. Herndon, Aerosolized coal fly ash: Risk factor for neurodegenerative disease. Journal of Advances in Medicine and Medical Research, 2018. 25(10): p. 1-11. PDF

40. Whiteside, M. and J.M. Herndon, Aerosolized coal fly ash: Risk factor for COPD and respiratory disease. Journal of Advances in Medicine and Medical Research, 2018. 26(7): p. 1-13. PDF

41. Whiteside, M. and J.M. Herndon, Geoengineering, coal fly ash and the new heart-Iron connection: Universal exposure to iron oxide nanoparticulates. Journal of Advances in Medicine and Medical Research, 2019. 31(1): p. 1-20. PDF

42. Herndon, J.M. and M. Whiteside, Contamination of the biosphere with mercury: Another potential consequence of ongoing climate manipulation using aerosolized coal fly ash J. Geog. Environ. Earth Sci. Intn., 2017. 13(1): p. 1-11. PDF

43. Herndon, J.M. and M. Whiteside, Unacknowledged potential factors in catastrophic bat die-off arising from coal fly ash geoengineering. Asian Journal of Biology, 2019. 8(4): p. 1-13. PDF

44. Herndon, J.M., D.D. Williams, and M. Whiteside, Previously unrecognized primary factors in the demise of endangered torrey pines: A microcosm of global forest die-offs. J. Geog. Environ. Earth Sci. Intn. , 2018. 16(4): p. 1-14. PDF

45. Whiteside, M. and J.M. Herndon, Previously unacknowledged potential factors in catastrophic bee and insect die-off arising from coal fly ash geoengineering Asian J. Biol., 2018. 6(4): p. 1-13. PDF

46. Whiteside, M. and J.M. Herndon, Aerosolized coal fly ash: A previously unrecognized primary factor in the catastrophic global demise of bird populations and species. Asian J. Biol., 2018. 6(4): p. 1-13. PDF

47. Whiteside, M. and J.M. Herndon, Role of aerosolized coal fly ash in the global plankton imbalance: Case of Florida's toxic algae crisis. Asian Journal of Biology, 2019. 8(2): p. 1-24. PDF

48. Herndon, J.M., Adverse agricultural consequences of weather modification. AGRIVITA Journal of agricultural science, 2016. 38(3): p. 213-221. PDF

49. Herndon, J.M., Aluminum poisoning of humanity and Earth's biota by clandestine geoengineering activity: implications for India. Curr. Sci., 2015. 108(12): p. 2173-2177. PDF

50. Herndon, J.M., Obtaining evidence of coal fly ash content in weather modification (geoengineering) through analyses of post-aerosol spraying rainwater and solid substances. Ind. J. Sci. Res. and Tech., 2016. 4(1): p. 30-36. PDF

51. Moreno, N., et al., Physico-chemical characteristics of European pulverized coal combustion fly ashes. Fuel, 2005. 84: p. 1351-1363.

52. Herndon, J.M. and M. Whiteside, Further evidence of coal fly ash utilization in tropospheric geoengineering: Implications on human and environmental health. J. Geog. Environ. Earth Sci. Intn., 2017. 9(1): p. 1-8. PDF

53. Chen, Y., et al., Characterization of ultrafine coal fly ash particles by energy-filtered TEM. J. Microscopy, 2005. 217(3): p. 225-234.

54. Suloway, J.J., et al., Chemical and toxicological properties of coal fly ash, in Environmental Geology Notes 1051983, Illinois Department of Energy and Natural Resources: Illinois.

55. McCain, J.D., et al., Electrostatic enhancement of fabric filter performance. Environmental science \& technology, 1984. 18(9): p. 635-641. 
56. Zhuang, Y., et al., Experimental and theoretical studies of ultra-fine particle behavior in electrostatic precipitators. Journal of Electrostatics, 2000. 48(3): p. 245-260.

57. Levandowski, J. and W. Kalkreuth, Chemical and petrographical characterization of feed coal, fly ash and bottom ash from the Figueira Power Plant, Paraná, Brazil. International Journal of Coal Geology, 2009. 77(3-4): p. $269-281$.

58. Srikanth, S. and G.N. Raju, Quantitative Study of Trace Elements in Coal and Coal Related Ashes using PIXE. Journal of the Geological Society of India, 2019. 94(5): p. 533-537.

59. Hvistendahl, M., Coal ash is more radioactive than nuclear waste, in Scientific American, December 13, 2007.

60. Moteki, N., et al., Anthropogenic iron oxide aerosols enhance atmospheric heating. Nature communications, 2017. 8: p. 15329.

61. Shamjad, P., et al., Refractive index and absorption attribution of highly absorbing brown carbon aerosols from an urban Indian City-Kanpur. Scientific reports, 2016. 6: p. 37735.

62. World Health Organization, Health effects of black carbon, 2012.

63. Zhou, L., et al., Carbon black nanoparticles induce pulmonary fibrosis through NLRP3 inflammasome pathway modulated by miR-96 targeted FOXO3a. Chemosphere, 2020. 241: p. 125075.

64. Herndon, J.M., Evidence of variable Earth-heat production, global non-anthropogenic climate change, and geoengineered global warming and polar melting. J. Geog. Environ. Earth Sci. Intn., 2017. 10(1): p. 16. PDF

65. http://svs.gsfc.nasa.gov/cgi-bin/details.cgi?aid=20010

66. Vogel, E., et al., The effects of climate extremes on global agricultural yields. Environmental Research Letters, 2019. 14(5): p. 054010.

67. Scheelbeek, P.F., et al., Effect of environmental changes on vegetable and legume yields and nutritional quality. Proceedings of the National Academy of Sciences, 2018. 115(26): p. 6804-6809.

68. Tigchelaar, M., et al., Future warming increases probability of globally synchronized maize production shocks. Proceedings of the National Academy of Sciences, 2018. 115(26): p. 6644-6649.

69. https://www.nytimes.com/2019/04/30/dining/farming-climate-change.html

70. Tie, X., et al., Effect of heavy haze and aerosol pollution on rice and wheat productions in China. Scientific reports, 2016. 6: p. 29612.

71. El-Shobokshy, M.S. and F.M. Hussein, Degradation of photovoltaic cell performance due to dust deposition on to its surface. Renewable Energy, 1993. 3(6-7): p. 585-590.

72. Landrigan, P.J., et al., The Lancet Commission on pollution and health. The lancet, 2018. 391(10119): p. $462-512$.

73. Friedrich, M., Air pollution is greatest environmental threat to health. JAMA, 2018. 319(11): p. 1085-1085.

74. Ambient air pollution - a global assessment of exposure and burden of disease., in WHO Library Cataloguing-in Publication 2016, World Health Organization, Geneva.

75. Kampa, M. and E. Castanas, Human health effects of air pollution Environmental Pollution, 2008. 151 : p. $362-367$.

76. Tegen, I. and A.A. Lacis, Modeling of particle size distribution and its influence on the radiative properties of mineral dust. J. Geophys. Res., 1996. 101(D14): p. 19237-19244.

77. Mossman, B.T., et al., Mechanisms of action of inhaled fibers, particles and nanoparticles in lung and cardiovascular diseases. Particle and Fiber Toxicology 2007. 4: p. 4.

78. A., U.S.E.P., Integrated science assessment for particulate matter (final report) U.S. Environmental Protection Agency, 2009: Washington, DC.

79. Sutto, T.E., Magnetite fine particle and nanoparticle environmental contamination from industrial uses of coal. Environmental pollution, 2018. 243: p. 528-533.

80. Maher, B.A., et al., Magnetite pollution nanoparticles in the human brain. Proc. Nat. Acad. Sci., 2016. 113(39): p. 1079710801.

81. Plascencia-Villa, G., et al., High-resolution analytical imaging and electron holography of magnetite particles in amyloid cores of Alzheimer's disease. Scientific Reports, 2016. 6: p. 24873. 
Herndon, J. M., \& Whiteside, M. (2020) Global Envionment Warfare. Advances in Social Sciences Research Journal, 7(4) 411-422.

82. Calderón-Garcidueñas, L., et al., Combustion-and friction-derived magnetic air pollution nanoparticles in human hearts. Environmental Research, 2019: p. 108567.

83. Jeremy, W., Air pollution and brain health: an emerging issue. Lancet, 2017. 390: p. 1345-422.

84. Maclntyre, E.A., et al., Air pollution and respiratory infections during early childhood: an analysis of 10 European birth cohorts within the ESCAPE Project. Environmental health perspectives, 2013. 122(1): p. 107-113.

85. Kilian, J. and M. Kitazawa, The emerging risk of exposure to air pollution on cognitive decline and Alzheimer's diseaseevidence from epidemiological and animal studies. Biomedical journal, 2018.

86. Weuve, J., et al., Exposure to particulate air pollution and cognitive decline in older women. Archives of internal medicine, 2012. 172(3): p. 219-227.

87. Calderón-Garcidueñas, L., et al., Air pollution and brain damage. Toxicologic Pathology, 2002. 30(3): p. $373-389$.

88. Calderon-Garciduenas, L., et al., Early Alzheimer'd and Parkinson's diese pathology in urban children: Friend verses foe response - it's time to face the evidence. BioMed Research International, 2013. 32: p. 650-658.

89. Pires, A., et al., Pre- and postnatal exposure to ambient levels of urban particulate matter (PM2.5) affects mice spermatogenesis. Inhalation Toxicology: International Forum for Respiratory Research: DOI: 10.3109/08958378.2011.563508, 2011. 23(4).

90. Villeneuve, P.J., et al., Residential exposure to fine particulate matter air pollution and incident breast cancer in a cohort of Canadian women. Environmental Epidemiology, 2018. 2(3): p. e021.

91. Becerra, T.A., et al., Ambient air pollution and autism in Los Angeles county, California. Environmental health perspectives, 2012. 121(3): p. 380-386.

92. Talbott, E.O., et al., Fine particulate matter and the risk of autism spectrum disorder. Environmental Research, 2015. 140: p. 414-420.

93. Conticini, E., B. Frediani, and D. Caro, Can atmospheric pollution be considered a co-factor in extremely high level of SARS-CoV-2 lethality in Northern Italy? Environmental Pollution, 2020: p. 114465.

94. $\mathrm{Wu}, \mathrm{X}$., et al., Exposure to air pollution and COVID-19 mortality in the United States. medRxiv, 2020: p. 2020.04.05.20054502.

95. Carrington, D. and M. Taylor, Air pollution is the 'new tobacco', warns WHO head, in The Guardian2018.

96. Conference, I.H., Constitution of the World Health Organization. 1946. Bulletin of the World Health Organization, 2002. 80(12): p. 983. 